\title{
Burnout dan Dimensi Kepribadian Conscientiousness terhadap Performansi Kerja Karyawan
}

\author{
Nandy Agustin Syakarofath \\ Fakultas Psikologi Universitas Muhammadiyah Malang \\ nandy.syakarofath@umm.ac.id
}

\begin{abstract}
Abstrak
Performansi kerja adalah hasil evaluasi dari kinerja yang dicapai oleh karyawan didalam menyelesaikan tugas dan tanggung jawabnya. Secara umum performansi kerja dapat dipengaruhi oleh faktor eksternal dan internal. Penelitian ini bertujuan untuk menguji signifikansi dua faktor eksternal dan internal yang dapat mempengaruhi performansi kerja individu. Sampel penelitian ini adalah 70 orang karyawan (53 perempuan, 17 laki-laki). Pengumpulan data dalam penelitian ini menggunakan skala Maslach Burnout Inventory (MBI), skala dimensi kepribadian conscientiousness dan self report berupa performansi kerja. Berdasarkan hasil perhitungan analisis regresi berganda kedua variabel prediktor penelitian ini menjelaskan adanya peran sebesar $21,9 \%$ dengan varians (adjusted $\mathrm{R} 2=0.219, \mathrm{~F}(9,378)=0,000 \mathrm{p}<0,05)$. Implikasi dari penelitian ini adalah burnout dan kepribadian conscientiousness memiliki hubungan terhadap performansi kerja.
\end{abstract}

Kata kunci :Burnout, performansi kerja, conscientiousness, karyawan

\begin{abstract}
Work performance is the result of evaluating the performance achieved by employees in completing their duties and responsibilities. In general, work performance can be influenced by external and internal factors. This study aims to examine the significance of two external and internal factors that can affect individual work performance. The sample of this study was 70 employees (53 female, 17 male) obtained from the Maslach Burnout Inventory (MBI) Scale, the scale of conscientiousness personality dimensions and self-report in the form of work performance. Based on analysis by multiple regression both predictor variables this study explains the role of $21.9 \%$ with variance (adjusted $\mathrm{R} 2=0.219, \mathrm{~F}(9,378)=0,000 \mathrm{p}<0.05$ ). The result shows that there is a positive relation between burnout and conscientiousness personality towards work performance.
\end{abstract}

Keywords: Burnout, work performance, conscientiousness, employees

\section{PENDAHULUAN}

Mencari pekerjaan adalah hal mutlak yang dilakukan oleh individu. Upaya mencari pekerjaan tersebut adalah cara untuk memenuhi kebutuhan hidup sehari-hari serta sebagai media aktualisasi diri (Uysal, Aydemir, \& Genç, 2017). Banyaknya lowongan pekerjaan juga diimbangi dengan banyaknya pelamar pekerjaan dengan berbagai latar belakang pendidikan yang berbeda. Dalam menerima karyawanpun perusahaan memiliki prosedur yang ketat sehingga semua pelamar harus bersaing untuk dapat diterima pada bidang pekerjaan yang diinginkan. Bagi karyawan yang telah diterima harus mampu menunjukkan kemampuan dan keahliannya secara kontinu dikarenakan persaingan tidak hanya untuk mendapatkan kursi diawal saja akan tetapi dalam proses selanjutnya kinerja karyawan juga harus ditingkatkan untuk mencapai tujuan organisasi. Tercapainya tujuan sebuah organisasi sangat ditentukan kualitas dan performansi kerja individu yang bekerja didalamnya oleh karena itu ia merupakan aset yang penting (Susiawan \& Muhid, 2015).

Performansi kerja yang tinggi menunjukkan kepuasan yang paling nyata dirasakan oleh seseorang yang mempunyai motif keberhasilan yang tinggi dan apabila dikaitkan dengan organisasi, performansi kerja karyawan merupakan salah satu pemberi sumbangsih atas kemajuan suatu perusahaan. Karakas (2010) menyebutkan bahwa seseorang dikatakan mempunyai performansi kerja yang baik apabila telah mengerahkan segenap usaha untuk 
mencapai standart pekerjaan yang telah ditentukan. Sebaliknya, jika tidak dapat memenuhi standar yang ditentukan maka performansinya dianggap kurang baik. Hal ini menegaskan pentingnya untuk dilakukan sebuah penilaian terhadap performansi kerja karyawan agar kualitas kerja didalam perusahan atau organisasi yang bersangkutan tetap terjaga. Penilaian performansi kerja adalah proses dimana organisasi-organisasi mengevaluasi atau menilai kinerja karyawannya untuk dapat memberikan umpan balik tentang pelaksanaan kerja (Handoko, 2001).

Menurut Lingga (2019) survey yang dilakukan Human Development Index (HDI) menyebutkan bahwa saat ini Indonesia masih termasuk sebagai negara dengan daya saing tenaga kerja yang rendah dibandingkan dengan beberapa negara lainnya di Asia seperti Singapura, Malaysia dan Brunai Darussalam , padahal pertumbuhan industri di Indonesia sangat pesat. Hal ini diperkuat oleh pencatatan data yang dilakukan oleh World Economic Forum (WEF) pada Tahun 2012 bahwasanya daya saing Indonesia berada pada peringkat ke50 dari 144 negara (Darwanto, 2012). Selain itu tentang Indeks Pencapaian Teknologi dan Indeks Pembangunan Manusia Indonesia menempati urutan 124 dari 178 negara, dan keadaan perekonomian Indonesia pertumbuhan produk domestik brutonya (PDB) 2012 yang tumbuh hanya $6,2 \%$. Hal ini menunjukkan bahwa daya saing Indonesia masih rendah dibandingkan perusahaan dinegara lainnya. Kondisi rendahnya persaingan dalam berbagai bidang di Indonesia dapat disebabkan oleh beberapa hal, salah satunya adalah stress kerja.

Stress yang dialami karyawan dapat berdampak positif dan negatif. Menurut Christy dan Amalia (2018) dampak positif stres dapat meningkatkan (fungsional) performansi kerja, sedangkan dampak negatifnya dapat menghambat atau merusak (infungsional) performansi kerja. Hal ini tergantung pada seberapa besar tingkat stress yang dialami. Tidak adanya tantangan kerja, performansi kerja juga cenderung rendah karena tidak ada usaha untuk menghadapi tantangan. Sedangkan dengan meningkatnya stress, performansi kerja cenderung naik karena stres membantu karyawan mengerahkan kemampuannya dalam memenuhi berbagai persyaratan atau kebutuhan pekerjaan, tentunya dalam porsi batas toleransi kesanggupan karyawan. Khamisa, Peltzer, Ilic, dan Oldenburg (2016) menyebutkan bahwa stress kerja yang dialami oleh karyawan sangat erat kaitannya dengan burnout. Dampak negatif burnout terhadap sikap kerja karyawan merujuk kepada perilaku yang tidak diinginkan seperti keterlibatan kerja yang lebih rendah, mengurangi tugas kinerja, dan peningkatan turnover intentions (Rizka, 2013). Lebih jauh, bahkan burnout diasosiasikan dapat berkontribusi terhadap adanya kecemasan dan depresi (Koutsimani, Montgomery, \& Georganta, 2019).

Maslach, Jackson, dan Leiter (1996) burnout sebagai sindrom hebat karena stres yang berkepanjangan ditempat kerja. Kondisi burnout dianggap sebuah sindrom yang dapat dijelaskan melalui tiga dimensi berupa kelelahan emosional (emotional exhaustion), sinisme atau depersonalisasi dan personal accomplishment (prestasi diri). Karyawan yang mengalami burnout dapat mempengaruhi kinerja karyawan, khususnya bagi pekerjaan human-service professional (profesi pelayanan publik) (Togia, 2005).

Reaksi setiap individu dalam mengahadapi burnout berbeda-berbeda, ada yang dapat mengatasinya dengan baik dan ada juga yang tidak sehingga menurunkan kinerjanya, bahkan dapat memicu karyawan untuk kompetitif. Berdasarkan reaksi dalam menghadapi burnout, terdapat berbagai jenis reaksi yang berkaitan dengan kepribadian. Handoko (2001) membagi menjadi dua tipe kepribadian A dan B. Karyawan dengan Tipe A adalah mereka yang lebih agresif, dan kompetitif, menetapkan standar-standar tinggi dan meletakkan diri mereka dibawah tekanan waktu yang ajeg (konstant), sedangkan karyawan dengan Tipe B lebih relaks dan tidak suka menghadapi masalah . Mereka menerima situasi-situasi yang ada dan tidak senang bersaing. Hal ini diperkuat oleh sebuah penelitian terkait kepribadian yang menyatakan adanya dampak negatif ekstraversion, agreeableness, openness terhadap burnout dan adanya dampak positif antara conscientiousness dan neuroticism (Reza, Anvari, Kalali, \& Gholipour, 2005). 
Dalam penelitian ini tipe kepribadian yang digunakan adalah dimensi conscientiousness dari teori five factor model of personality. Conscientiousness adalah derajat individu pada keteraturan, ketahanan, dan motivasi dalam perilaku yang mengarah pada tujuan (Simmering, Colquitt, Noe, \& Porter, 2003). Bahkan Roberts, Lejuez, Krueger, Richards, dan Hill (2014) menyebutkan bahwa conscientiousness merupakan sebuah konstruk kepribadian yang menjadi penentu utama kesehatan individu, proses penuaan yang positif (positive aging), dan modal manusia (human capital). Hal ini sesuai dengan pendapat Sleem dan El-Sayed (2011) yang menyebutkan bahwa conscientiousness merupakan faktor yang berkontribusi positif didalam semua jenis pekerjaan. Secara khusus disebutkan bahwa conscientiousness memiliki hubungan kuat dengan performansi kerja (Bui, 2017; Hassan, Akhtar, \& Y1lmaz, 2018; Soto, 2018). Artinya, karyawan yang memiliki tingkat conscientiousness yang tinggi dapat menunjukkan fungsional kerja yang baik.

Berdasarkan uraian diatas didapatkan dipahami bahwa burnout dan kepribadian conscientiousness merupakan dua unsur penting yang dapat mempengaruhi performansi kerja individu, untuk itu perlu penelitian yang dapat menjelaskan hubungan kedua variabel tersebut dengan performansi kerja. Kontribusi penelitian ini adalah pada konteks variabel conscientiousness yang menjadi pembeda dengan penelitian-penelitian sebelumnya, karena penelitian-penelitian sebelumnya lebih banyak mengkaji burnout yang terjadi dan hubungannya dengan performansi kerja karyawan.

\section{METODE}

Penelitian ini dilakukan dengan menggunakan metode kuantitatif. Subjek penelitian 70 orang yang bersatus karyawan di perusahaan yang ada di Kabupaten Pamekasan, terdiri dari 53 karyawan perempuan dan 17 karyawan laki-laki. Teknik pengambilan sampel menggunakan purposive sampling, dengan karakteristik: 1) berstatus sebagai karyawan dan terdaftar disalah satu perusahan, 2) memiliki daftar evaluasi kerja berupa penilaian pencapaian kerja oleh atasan.

Data dikumpulkan dengan menggunakan dua skala yaitu skala burnout maslach burnout inventory (MBI) yang dikembangkan oleh Maslach dan Jackson (1981) untuk mengukur burnout $(\alpha=0,891)$. Untuk mengukur conscientiousnesss skala yang digunakan adalah hasil pengembangan oleh John dan Srivastava (1999) $(\alpha=0,829)$. Sedangkan untuk mengukur performansi kerja, menggunakan self report perorangan berupa evaluasi atau penilaian yang dimiliki oleh perusahaan dengan contoh aitem sebagai berikut: 1) saya melaksanakan pekerjaan sesuai dengan prosedur standar kerja yang telah ditentukan, 2) pakerjaan yang saya lakukan dikantor seringkali menumpuk dan tidak terselesaikan setiap harinya, 3) saya tidak menyukai dengan pekerjaan yang membutuhkan rutinitas tinggi.

\section{HASIL}

Tabel 1. Karakteristik subjek

\begin{tabular}{lccc}
\hline \multicolumn{1}{c}{ Jenis Kelamin } & Jumlah & Persentase & Total Persentase \\
\hline Laki-laki & 53 & $75.71 \%$ & \multirow{2}{*}{$100 \%$} \\
Perempuan & 17 & $24.29 \%$ & \\
\hline
\end{tabular}

Tabel 2. Sebaran $t$-score burnout, kepribadian conscientiousness dan performansi kerja

\begin{tabular}{lcccc}
\hline & Kategori & Interval & Frekuensi & Persentase \\
\hline Burnout & Tinggi & t-score $>50$ & 36 & $51,4 \%$ \\
& Rendah & t-score $<50$ & 34 & $48,6 \%$ \\
\cline { 2 - 5 } & Total & & 70 & $100 \%$ \\
\hline Kepribadian & Kategori & Interval & Frekuensi & Persentase \\
\hline
\end{tabular}


PSYCHOPOLYTAN (Jurnal Psikologi)

ISSN CETAK

: 2614-5227

VOL. 3 No. 1, Agustus 2019

ISSN ONLINE : :2654-3672

\begin{tabular}{lcccc}
\cline { 2 - 5 } conscientiousness & Tinggi & t-score $>50$ & 33 & $47,1 \%$ \\
\cline { 2 - 5 } & Rendah & t-score $<50$ & 37 & $52,9 \%$ \\
\cline { 2 - 5 } & Total & & 70 & $100 \%$ \\
\hline Performansi kerja & Kategori & Interval & Frekuensi & Persentase \\
\cline { 2 - 5 } & Tinggi & t-score $>50$ & 42 & $60 \%$ \\
\cline { 2 - 5 } & Rendah & t-score $<50$ & 28 & $40 \%$ \\
\cline { 2 - 5 } & Total & & 70 & $100 \%$ \\
\hline
\end{tabular}

Berdasarkan tabel 2, di atas, hasil penelitian menunjukkan bahwa hasil deskripsi keseluruhan subjek penelitian adalah dari 70 subjek, sebanyak 36 orang atau 51,4\% mengalami burnout yang termasuk kedalam kategori tinggi dan 34 orang lainnya atau 48,6\% termasuk kedalam kategori rendah. Selanjutnya, pada tingkat kepribadian conscientiousness sebanyak 33 orang berada pada kategori tinggi sebanyak 47,1\% dan 37 orang lainnya atau $52,9 \%$ memiliki dimensi kepribadian conscientiousness yang rendah. Adapun performansi kerja, terdapat 42 orang karyawayan dinilai memiliki performansi kerja yang tinggi sebanyak $60 \%$ dan 28 orang lainnya dianggap memiliki performansi kerja yang rendah sebanyak $40 \%$.

Tabel 3. Penjabaran model regresi dari variabel penelitian

\begin{tabular}{lcc}
\hline \multicolumn{1}{c}{ Model } & R square & Sig \\
\hline $\begin{array}{l}\text { Burnout, kepribadian conscientiousness } \\
\text { dan prestsi kerja }\end{array}$ & 0,219 & 0.000 \\
\hline Keterangan : $* * \mathrm{p}<0,01 * \mathrm{p}<0,05$ & &
\end{tabular}

Melalui tabel 3, di ketahui hasil perhitungan regresi berganda burnout, kepribadian constientiousness dan performansi kerja memiliki nilai sgnifikansi $0,000(\mathrm{p}<0.01)$ dengan $\mathrm{R}$ square 0,219 . Artinya, secara simultan kedua variabel yang diteliti berperan terhadap performansi kerja, dengan sumbangan efektif sebesar sebesar 21,9\%.

\section{PEMBAHASAN}

Berdasarkan analisis data yang dilakukan didapat hasil bahwa burnout dan kepribadian conscientiousness secara bersama-sama dapat berperan terhadap performansi kerja. Hal ini sesuai dengan penelitian Bakker, Demerouti, dan Sanz-Vergel (2014) bahwasanya performansi kerja seseorang dipengaruhi oleh burnout dan beberapa faktor perantara lainnya seperti optimisme dan kompensasi didalam bekerja. Sejalan dengan pernyataan tersebut disebukan bahwa performansi kerja individu adalah aspek penting dalam tercapainya tujuan organisasi (Tsai, Yen, Huang, \& Huang, 2007).

Burnout sendiri dianggap sebagai konsekuensi dari kondisi kerja yang tidak menyenangkan, ditandai dengan simultan mengalami gejala kelelahan dan pelepasan dari pekerjaan seseorang (Demerouti, Nachreiner, Bakker, \& Schaufeli, 2001; C Maslach \& Leiter, 1997). Sedangkan kepribadian conscientiousness adalah suatu kemampuan pada diri individu untuk dapat mengontrol dorongan-dorongan atau impuls baik yang negatif. Keduanya merupakan faktor yang berasal dari internal dan eksternal subjek didalam mempengaruhi performansi kerja.

Hubungan burnout dengan performansi kerja pada hasil penelitian ini selaras dengan penelitian yang menyebutkan bahwa burnout memberikan dampak negatif terhadap kinerja karyawan, sikap yang mengarah kepada perilaku yang tidak diinginkan, seperti keterlibatan kerja yang rendah, kinerja tugas berkurang, dan meningkatnya pergantian karyawan(C Maslach \& Leiter, 1997; Christina Maslach \& Jackson, 1981). Secara umum burnout dikaitkan dengan 
munculnya perasaan negatif, seperti perasaan tidak puas terhadap pekerjaannya sehingga membuat performansinya menurun (Aksu, Murat and Tememloglu, 2015).

Sedangkan temuan terkait hubungan kepribadian conscientiousness dengan performansi kerja dianggap sesuai dengan penelitian yang dikemukakan oleh Pervin, Cervone, dan Oliver P John (2010) serta Sydney-Agbor, Nwankwo, Iroegbu, Obi, dan Agu (2013) menyebutkan bahwa kepribadian conscientiousness merupakan karakteristik kepribadian ini digunakan untuk mengidentifikasi bagaimana karakteristik individu seperti ketekunan, motivasi, kejujuran dan ketangguhan didalam bekerja. Individu yang memiliki level conscientiousness yang tinggi menunjukkan perilaku yang terorganisir, dapat diandalkan, pekerja keras, memiliki disiplin diri, tepat waktu, cermat, rapi, tekun dan berambisi. Hal ini dianggap sebagai faktor penentu terhadap peningkatan performansi kerja karyawan.

Kondisi burnout yang dialami oleh individu meski memiliki kecenderungkan berdampak negatif terhadap perilaku kerja apabila berinteraksi bersamaan dengan kepribadian conscientiousness, maka efek negatif itu dapat diminimalisir. Kepribadian conscientiousness dianggap sebagai faktor yang dapat membantu individu untuk memfilter dan menjadi penahan dampak burnout yang terjadi (Azeem, 2013; Kim, Jörg, \& Klassen, 2019). Seseorang dengan tingkat consientiosness yang cukup baik dapat membantu seseorang untuk dapat lebih fokus mencapai prestasi, sangat bertanggung jawab dan terorganisir (John, Naummann, \& Soto, 2008). Hal sejalan dengan temuan yang ada, meski didapatkan data karyawan yang memiliki penilaian burnout yang tinggi sebesar 51,4\%, tetapi performansi kerjanya juga dapat dikatakan cukup baik dengan penilaian performansi kerja yang tinggi sebanyak 60\%. Hal ini diasumsikan karena adanya faktor pendukung dari kepribadian conscientiousness yang dimiliki oleh karyawan.

As'ad (1991) berpendapat bahwa faktor-faktor yang dapat mempengaruhi prestasi kerja seseorang, meliputi faktor fisik dan faktor psikis, dari segi fisik antara lain adalah bentuk tubuh dan komposisinya, taraf kesehatan fisik, serta kemampuan panca indera, adapun dari segi faktor psikis antara lain adalah bakat, inteligensi, pendidikan, minat, motivasi, serta kepribadian. Adapun yang dimaksud kepribadian dalam penelitian ini adalah kepribadian conscientiousness.

Subjek penelitian adalah para pekerja yang bergerak dibidang pelayanan jasa asuransi. Profesi yang bergerak dalam bidang pelayanan jasa dianggap memiliki tantangan tinggi dan dibutuhkan kualitas individu yang mumpuni, hal ini tercermin dalam kepribadian tertentu yang dimiliki oleh karyawan untuk mendukung performansi kerjanya. Ishwara (2005) menyebutkan bahwa karakteristik kepribadian tersebut antara lain pekerja keras, pantang menyerah, tekun, teliti, disiplin, dapat dipercaya dan bertanggungjawab. Kualitas kepribadian tersebut sesuai dengan karakteristik dalam dimensi kepribadian conscientiousness.

Tingginya subjek yang mengalami burnout tidak menyebabkan rendahnya performansi kerja yang bersangkutan dikarenakan nilai prosentase dimensi kepribadian conscientiousness masih bersifat normal yaitu dibuktikan dengan prosentase conscientiousness tinggi sebesar 47,1\%. Hal ini sesuai dengan penelitian yang dilakukan oleh (Noormaysuti, Anggraini, \& Sumiati, 2013) yang menyatakan bahwa adanya hubungan yang positif antara kepribadian conscientiousness dengan kinerja guru, yaitu semakin tinggi kepribadian conscientiousness maka akan semakin tinggi kinerja guru yang bersangkutan. Hal ini dapat dipahami bahwasanya kondisi burnout yang dialami subjek penelitian tidak selalu berdampak negatif terhadap performansi kerjanya, dalam tingkatan tertentu bagi beberapa individu justru menjadi tantangan tersendiri yang dapat memacu peningkatan performansi kerja hal ini dikarenakan karyawan memiliki toleransi yang berbeda-beda dalam menghadapi keadaan burnout yang di dihadapi dan hal ini bergantung kepada kontribusi dimensi kepribadian conscientiousness pada karyawan yang bersangkutan. 


\section{SIMPULAN}

Berdasarkan hasil penelitian yang telah dilakukan, maka dapat diambil kesimpulan bahwa burnout dan kepribadian conscientiousness secara bersama-sama berpengaruh terhadap performansi kerja karyawan. Semakin tinggi burnout yang dirasakan tidak kemudian otomatis berdampak negatif terhadap kehidupan kerja karyawan apabila ada interaksi bersamaan dengan kepribadian conscientiousness yang merupakan filter atau penahan dampak negatif dari burnout yang dirasakan. Dengan demikin burnout tidak selalu memunculkan dampak negatif jika ada faktor internal individu yang menyertainya.

\section{DAFTAR PUSTAKA}

Aksu, Murat and Tememloglu, E. (2015). Effects of Burnout on Employees' Satisfaction a Research at 3, 4 and 5 Star Hotels in Canakkale City Center. International Journal of Business and Social Science, 6(1), 220-221. Retrieved from https://pdfs.semanticscholar.org/6977/c0fb67dbf6a4e9795cd00a561c2f5ccc06f4.pdf

As'ad. (1991). Seri Ilmu Manajemen Sumber Daya Manusia Psikologi Industri. Bandung: Alumni.

Azeem, D. S. M. (2013). Conscientiousness, Neuroticism and Burnout among Healthcare Employees. International Journal of Academic Research in Business and Social Sciences, 3(7). https://doi.org/10.6007/ijarbss/v3-i7/68

Bakker, A. B., Demerouti, E., \& Sanz-Vergel, A. I. (2014). Burnout and Work Engagement: The JD-R Approach. Annual Review of Organizational Psychology and Organizational Behavior, 1(1), 389-411. https://doi.org/10.1146/annurev-orgpsych-031413-091235

Bui, H. T. M. (2017). Big five personality traits and job satisfaction: Evidence from a national sample. Journal of General Management, 42(3), 21-30. https://doi.org/10.1177/0306307016687990

Christy, N. A., \& Amalia, S. (2018). Pengaruh Stres Kerja Terhadap Kinerja Karyawan The Influence of Job Stress on Employees Job Performance. Jurnal Riset Bisnis Dan Investasi, 3(2), 74. https://doi.org/10.35697/jrbi.v3i2.935

Darwanto, H. (2012). Penurunan Peringkat Daya Saing Indonesia Tahun 2012. Retrieved from https://www.bappenas.go.id/en/blog/penurunan-peringkat-daya-saing-indonesia-tahun2012/

Demerouti, E., Nachreiner, F., Bakker, A. B., \& Schaufeli, W. B. (2001). The job demandsresources model of burnout. Journal of Applied Psychology, 86(3), 499-512. https://doi.org/10.1037/0021-9010.86.3.499

Handoko, T. . (2001). Manajemen personalia dan sumber daya manusia (kedua). Yogyakarta: BPFE.

Hassan, S., Akhtar, N., \& Y1lmaz, A. K. (2018). Impact of the Conscientiousness as Personality Trait on both Job and Organizational Performance Impact of the Conscientiousness as Personality Trait on both Job and Organizational Performance Keywords : Nature and Science, 9(12), 173-179.

Ishwara, L. (2005). Catatan-Catatan Jurnalisme Dasar. Jakarta: Kompas.

John, O. P., Naummann, L., \& Soto, C. . (2008). Paradigm shift to the integrative big five trait taxonomy. In \& L. A. P. O. P. John, R. W. Robins (Ed.), Handbook of Personality: Theory 
and Research (3 rd). New York, NY: Guilford.

John, O. P., \& Srivastava, S. (1999). The Big Five Trait Taxonomy: History, Measurement, and Theoretical Perspectives. In Handbook of Personality: Theory and Research (Vol 2, pp. 102-138). New York: Guilford Press.

Karakas, F. (2010). Spirituality and performance in organizations: A literature review. Journal of Business Ethics, 94(1), 89-106. https://doi.org/10.1007/s10551-009-0251-5

Khamisa, N., Peltzer, K., Ilic, D., \& Oldenburg, B. (2016). ScienceDirect Effect of personal and work stress on burnout, job satisfaction and general health of hospital nurses in South Africa. Health SA Gesondheid, 22, 252-258. https://doi.org/10.1016/j.hsag.2016.10.001

Kim, L. E., Jörg, V., \& Klassen, R. M. (2019). A Meta-Analysis of the Effects of Teacher Personality on Teacher Effectiveness and Burnout. Educational Psychology Review, 31(1), 163-195. https://doi.org/10.1007/s10648-018-9458-2

Koutsimani, P., Montgomery, A., \& Georganta, K. (2019). The relationship between burnout, depression, and anxiety: A systematic review and meta-analysis. Frontiers in Psychology, 10(MAR), 1-19. https://doi.org/10.3389/fpsyg.2019.00284

Lingga, M. A. (2019). Bappenas: Kualitas Sumber Daya Manusia Indonesia Masih Menengah. Retrieved from https://money.kompas.com/read/2019/07/22/111200026/bappenas-kualitas-sumber-daya-manusia-indonesia-masih-menengah-

Maslach, C, \& Leiter, M. P. (1997). The truth about burnout: How organizations cause personal stress and what to do about it. Atlantic.

Maslach, Christina, \& Jackson, S. E. (1981). The measurement of experienced burnout. Journal of Organizational Behavior, 2(2), 99-113. https://doi.org/10.1002/job.4030020205

Maslach, Christina, Jackson, S. E., \& Leiter, M. P. (1996). The Maslach Burnout Inventory Manual. The Maslach Burnout Inventory, (June 2015), 191-217. https://doi.org/10.1002/job.4030020205

Noormaysuti, Anggraini, R., \& Sumiati, A. (2013). Hubungan antara Conscientiousness (kesadaran akan diri sendiri) dengan kinerja pada guru SMK Negeri di Jakarta Pusat. Jurnal Pendidikan Ekonomi Dan Bisnis (JPEB), 1(2), 70-87.

Pervin, L. A., Cervone, D., \& Oliver P John. (2010). Psikologi Kepribadian, Teori dan Penelitian Edisi kesembilan. Jakarta: Kencana.

Reza, M., Anvari, A., Kalali, N. S., \& Gholipour, A. (2005). How does personality affect on job burnout?, 2(2), 115-119.

Rizka, Z. (2013). Sikap terhadap pengembangan karir dengan burnout pada Karyawan. Jurnal Ilmiah Psikologi Terapan, 01(02), 1-21.

Roberts, B. W., Lejuez, C., Krueger, R. F., Richards, J. M., \& Hill, P. L. (2014). What is conscientiousness and how can it be assessed? Developmental Psychology, 50(5), 13151330. https://doi.org/10.1037/a0031109

Simmering, M. J., Colquitt, J. A., Noe, R. A., \& Porter, C. O. L. H. (2003). Conscientiousness, Autonomy Fit, and Development: A Longitudinal Study. Journal of Applied Psychology, 88(5), 954-963. https://doi.org/10.1037/0021-9010.88.5.954

Sleem, W. F., \& El-Sayed, N. M. (2011). The effect of job consientiousness on job perfomance. Nature and Science, 9(5), 1-8. 
Soto, C. . (2018). Big Five personality traits. In \& J. E. L. M. H. Bornstein, M. E. Arterberry, K. L. Fingerman (Ed.), The SAGE encyclopedia of lifespan human development (pp. 240 241). Thousand Oaks, CA: Sage.

Susiawan, S., \& Muhid, A. (2015). Kepemimpinan Transformasional, Kepuasan Kerja dan Komitmen Organisasi. Persona:Jurnal Psikologi Indonesia, 4(03), 304-313. https://doi.org/10.30996/persona.v4i03.725

Sydney-Agbor, N., Nwankwo, B. E., Iroegbu, M., Obi, T. C., \& Agu, S. A. (2013). The Big Five Personality Traits and Job Involvement: An Investigation of University Lecturers in South Eastern Nigeria. Open Science Repository Psychology, Online(open-access), e23050430. https://doi.org/10.7392/openaccess.23050430

Togia, A. (2005). Measurement of burnout and the influence of background characteristics in Greek academic librarians. Library Management, 26(3), 130-138. https://doi.org/10.1108/01435120510580870

Tsai, P. C. F., Yen, Y. F., Huang, L. C., \& Huang, I. C. (2007). A study on motivating employees' learning commitment in the post-downsizing era: Job satisfaction perspective. Journal of World Business, 42(2), 157-169. https://doi.org/10.1016/j.jwb.2007.02.002

Uysal, H. T., Aydemir, S., \& Genç, E. (2017). Maslow' S Hierarchy of Needs in 21St Century : the Examination of. Researches on Science and Art in 21st Century Turkey, (April 2018), 211-227. 